\title{
Relationship between rainfall and microbiological contamination of shallow groundwater in Northern Mozambique
}

\author{
S Godfrey ${ }^{1 *}$, F Timo $^{2}$ and M Smith ${ }^{3}$ \\ ${ }^{1}$ Water and Environmental Sanitation Project Officer, UNICEF Bhopal, India (formerly WEDC, UK) \\ ${ }^{2}$ Estação Agraria de Lichinga, Lichinga, Mozambique \\ ${ }^{3}$ Water, Engineering and Development Centre (WEDC), Loughborough University, UK
}

\begin{abstract}
Outbreaks of contamination events in many developing countries occur during periods of peak rainfall. This study presents evidence of direct pulse response of shallow groundwater contamination events to rainfall in Northern Mozambique. The objective of the paper is to establish both a statistical relationship between rainfall and contamination and to analyse the pathways through which runoff resulted in contamination. To achieve this, data from 25 wells were monitored over a 12-month period in Lichinga, Northern Mozambique, and then compared to historical rainfall from the previous 8 years. Categorical (soil survey) and parametric (water quality, rainfall, depth-to-water-table) data were further collected before, during and after the 4-month monomodal rains. Using logistic regression statistics, three distinct conclusions were drawn from the study. Firstly, the study demonstrated a direct pulse response between increased numbers of presumptive thermotolerant coliforms and enterococci bacteria. Secondly, the study observed high risk of contamination through localised, as opposed to aquifer pathways, and thirdly, the study noted a higher survival function and stability of presumptive enterococci bacteria as compared to presumptive thermotolerant coliforms in the environment and at depth.
\end{abstract}

Keywords: rainfall/runoff, contamination, groundwater monitoring, microbiological processes

\section{Introduction}

Studies of shallow groundwater contamination in developing countries have demonstrated a direct pulse-response between trends of rainfall and microbiological contamination (Barrel, 1979; Lewis et al.., 1980; Lewis et al.,1984; Wright, 1986). A recent study of springs in the weathered crystalline aquifers of Kampala, Uganda by Barret (2000) and Howard et al. (2003) demonstrated a significant deterioration in microbiological groundwater quality within 12 hours of a rainfall event (Barret et al., 2000; Howard et al., 2003). This study is supported by further evidence from studies undertaken in Peru, Gambia, Sierra Leone and Zambia regarding the seasonality of groundwater quality (Barrel, 1979; Wright, 1986; Utkilen et al., 1989; Bartram, 1996). For example, in a study of wells in rural villages in the Gambia, Barrel (1979) noted an increase of approximately 10 orders of magnitude of faecal contamination following the onset of the rains over a period of 6 days (Barrel, 1979). Further studies by Utkilen et al. (1989) in Zambia concluded that peaks in faecal contamination of wells were associated with rainfall as a result of surface flushing of faecal material (Utkilen et al., 1989).

However, in contrast to these views, studies of the seasonality of water quality in Sierra Leone noted decreasing rates of contamination during the wet season (Wright, 1986). The study examined levels of selected faecal indicator bacteria and incidence of Salmonella spp. over a one-year period. The study concluded that counts were generally increasing during the dry season culminating in peaks at the transition from dry to wet season. This increase was attributed to a lack of sanitation devel-

\footnotetext{
* To whom all correspondence should be addressed.

要 +91755 2466568; fax: +91 7552463623 ;

e-mail: sgodfrey@unicef.org

Received 21 January 2005; accepted in revised form 9 June 2005.
}

opment and the sporadic nature of rainfall patterns in the study area. Consequently, the human and animal waste was deposited at the soil surface and flushed into the water sources during the rains. Additionally, due to the water sources diminishing in the dry season, a lower level of dilution or concentration effect of faecal contamination was observed in the dry season resulting in higher detection levels (Wright, 1986).

Studies by Howard et al. (2003), although solely focused on spring contamination, provide a significant background to the development of the study presented in this paper. Their study highlights the importance of contamination of shallow springs by short-circuiting of sanitary headworks through "localised pathways" (Howard et al., 2003) It explores this alternative localised pathway by examining the microbiological contamination levels in springs with varied levels of sanitary protection during periods of high and low rainfall.

This paper widens the Howard et al. (2003) research to investigate microbiological contamination of 25 shallow wells over 12 months (November 2003 to October 2004) in Lichinga, Northern Mozambique. The aim of the study outlined in this paper was to identify the influence of rainfall and localised pathways on groundwater contamination. Based on the source-pathwayreceptor model of groundwater contamination, "localised" and "aquifer" pathways of contamination are defined as follows;

- Localised pathways - a rapid bypass mechanism where pathogens enter the intake of the water supply due to poor design and/or construction, the microbes having limited residence time in the saturated zone as a consequence.

- Aquifer pathways - where pathogens migrate through the subsoil from a faecal source to the water table (ARGOSS, 2002).

Field workers report that localised pathways are considered of high significance in Mozambique, where poor quality materials, limited quality control in construction and high levels of 


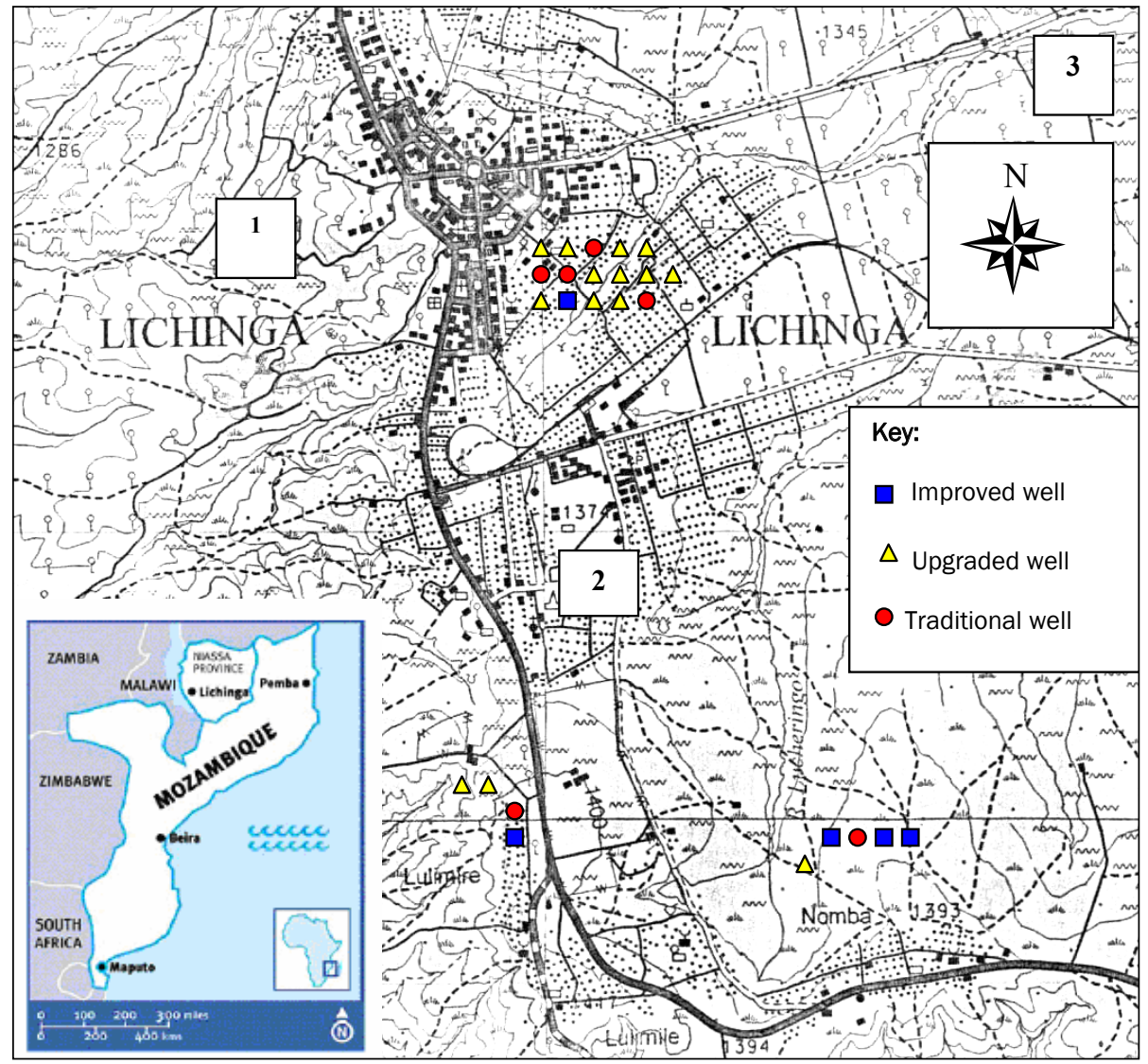

Figure 1

Location of sample points and rain-gauges in Lichinga

where:

improved well = concrete caisson

lined well with mechanised pump

upgraded well = brick lined well with windlass

traditional well = unlined well with rope and bucket

Note: Raingauges 1, 2, 3 are identified by white squares in Fig.1 faeces in the environment result in high levels of microbiological ingress (Tino, 2003). This paper discusses the relationship between rainfall and contamination in three well types with respect to the contamination pathways.

\section{Experimental}

The study was undertaken in the town of Lichinga, the capital of Niassa Province in Northern Mozambique, located at $13^{\circ} 18^{\prime} \mathrm{S}, 35^{\circ} 15^{\prime} \mathrm{E}$, through joint research between the UKbased Water, Engineering and Development Centre (WEDC), the Mozambique Estação Agraria de Lichinga (Agricultural Research Centre) and the UK charity WaterAid. Twenty five groundwater sources were selected using the statistical t-test based on 2 comparable means from 2 variables; existing levels of contamination (water quality) and population served. Using the t-test, the number of water points required with $95 \%$ confidence level of estimating average levels of contamination within $2 \%$ of the true value was calculated using Eqs.(1) and (2):

$$
\mathrm{n}_{\mathrm{o}}=\frac{\{t \mathrm{~S}\}^{2}}{r \mathrm{Y}^{2}}
$$

where:
$\mathrm{n}$ : first approximation of sample size
$t$ : confidence probability ( $\mathrm{t}$ statistics). This value is 1.64, 1.96 and 2.58 for confidence probabilities of 90 , 95 and $99 \%$ respectively
$\mathrm{S}:$ population standard deviation
$r$ : relative error
$\mathrm{Y}:$ population mean.

$$
\begin{aligned}
\mathrm{n} & =\frac{\mathrm{n}_{\mathrm{o}}}{\left(1+\frac{\mathrm{n}_{\mathrm{o}}}{\mathrm{N}}\right)} \\
\text { where: } & \\
\mathrm{n}: & \text { sample size } \\
\mathrm{N}: & \text { population size } \\
\mathrm{n}_{\mathrm{o}}: & \text { first approximation sample size (see Eq.(1)). }
\end{aligned}
$$

For a statistically valid sample, 20 water points would be required. These were selected from the communities outlined in Map 1 based on logistics, practicalities, ease of access, available water quality data and inclusion in an existing monitoring framework.

Data were initially collected from 20 water sources in three communities in Lichinga with an additional five traditional wells used as control sites (at least one of each located within a given sampling area). Sampling was undertaken twice per month immediately before the rains and at monthly intervals after their arrival to gauge the potential "pulse response" of levels of contamination in the shallow groundwater to rainfall. Stratified data collection was done on both categorical and parametric variables.

Categorical variables (or non-changing data) were single measurements. These included geographic positioning system (GPS) readings, a soil characterisation study based on particle size distribution (PSD) and soil classification tests and an engineering assessment. For the purpose of this paper, the soil characterisation methods will be discussed. The method for collecting soil characterisation data included the particle size distribution method and manual soil classification tests (Swartz et 
al., 2003). Methods used for testing PSD followed BS1377-2 (1990) and Barnes (2000) (BS1377-2, 1990; Barnes, 2000). A single soil sample was taken at each of the 25 wells and analysed in March 2004. Samples were riffled through a set of 5" sieves with sizes of $5 \mathrm{~mm}, 3.35 \mathrm{~mm}, 2 \mathrm{~mm}, 1.18 \mathrm{~mm}, 600 \mu \mathrm{m}, 425 \mu \mathrm{m}$, $300 \mu \mathrm{m}, 212 \mu \mathrm{m}, 150 \mu \mathrm{m}, 63 \mu \mathrm{m}$. PSD tests were supported by semi-qualitative manual tests using an augered sample from a depth of $0.5 \mathrm{~m}$ at a distance of $1 \mathrm{~m}$ from the well. This was done at each of the well sites. A segment of soil was extracted from the sample and analysed. The sample was classified based on the thumb and finger test outlined in the Ciba-Geigy Agrochemicals "Guide to Soil Identification" (CibaGeigy, 1986).

Physical methods were supported by in situ readings of the well geology. These included:

- GeoVision borehole camera readings of lined wells using a miniature colour monitor. This provided a quick view of both the geological formation and level of sanitary protection afforded by the lining of the well.

- Subsoil thickness visual observations of unlined traditional wells. These were logged as 0-1 m, 1-3 m, 4-5 $\mathrm{m}$ and $>5 \mathrm{~m}$.

Parametric variables (or continuous data) were collected either daily or monthly from November 2003 to October 2004. These included daily rainfall readings, monthly microbiological and physico-chemical data, and monthly depth-to-water-table and sanitary inspection data.

\section{Rainfall data collection}

Daily rainfall was measured using two $40 \mathrm{~mm}$ capacity Dipflex raingauges (Sites 1 and 2 as shown on Fig. 1 during the 12month period to understand the correlation between rainfall and contamination. This data was then compared to historical rainfall for the proceeding 8 years. Number 1 raingauge was located to the west of the city in a low lying area for data comparison to rainfall measurements at a higher altitude. Number 2 raingauge was located in the Agricultural Research Centre of Lichinga approximately 500 to $1000 \mathrm{~m}$ from the project site. Each was positioned on a 1.5 to $2.0 \mathrm{~m}$ high pole in an open area with a clear distance between the gauge and the nearest and tallest tree being twice the height of that tree (Gunston, 1997). The rainfall was measured at 17:00 on a daily basis during the 12-month data collection period (Gunston, 1997). Historical data from 1995 to date were also collected from the Meteorological Centre of Lichinga (marked as Number 3 on Fig. 1). Monthly average rainfall measured at Lichinga Airport for the period 1995 to 2003 was also obtained from the Meteorological Centre of Lichinga. However, it is possible that not all rainfall was measured during this period, the reasons for which are discussed within a later section.

\section{Water quality data collection}

Monthly water quality samples were tested at a centralised laboratory established in Lichinga following standard aseptic procedures (WHO, 2004) Samples were collected using sterile $60 \mathrm{ml}$ plastic sampling bottles. These were stored in cool bags at $<4{ }^{\circ} \mathrm{C}$ for a maximum of $6 \mathrm{~h}$ whilst field sampling was undertaken.

Two microbiological parameters were tested; Presumptive (rather than confirmed) enterococci and thermotolerant coliforms. Presumptive enterococci were isolated using azide Nutridiscs (AND), pre-impregnated membranes with sodium azide supplied by Schleicher and Schuell "Product Reference Number 10433003;" (WagTech, 2003). $50 \mathrm{~m} \ell$ samples were processed using membrane filtration (filter size of $45 \mu \mathrm{m}$ ) and applied to the ANDs. A $4 \mathrm{~h}$ resuscitation period at ambient temperature was observed prior to incubation at $44^{\circ} \mathrm{C}\left( \pm 0.5^{\circ} \mathrm{C}\right)$ for $44 \mathrm{~h}$. Although enterococci grow best at $37^{\circ} \mathrm{C}$, they are less selective at this temperature than when incubated at $44^{\circ} \mathrm{C}$ (Anon, 1994). Post-incubation, all red, maroon and pink bacterial colonies that were smooth and convex were identified using a handlens and recorded as presumptive enterococci (WagTech, 2003). Total plate counts were recorded per $100 \mathrm{~m} \ell$ by multiplying the number of presumptive enterococci in $50 \mathrm{~m} \ell$ by 2 . Confirmations were not possible at field level due to difficulties of preparation and storage of kanamycin aesculin azide agar plates.

The isolation and enumeration of thermotolerant coliforms were carried out using membrane filtration (WagTech, 2003). $50 \mathrm{~m} \ell$ samples were filtered through a Millipore $45 \mu \mathrm{m}$ nitrocellulose filter. Membrane lauryl sulphate medium was prepared with $50 \mathrm{~m} \ell$ de-ionised water in a membrane sulphate media measuring device "MMD" (WagTech, 2003). 2 m of the solution was applied to each filter pad. The filtered membrane was then placed on a pad and incubated at an ambient temperature of $28^{\circ} \mathrm{C}$ for $4 \mathrm{~h}$ to permit bacterial resuscitation, before being transferred to $44^{\circ} \mathrm{C}$ for $14 \mathrm{~h}$ incubation. Post-incubation, all yellow colonies were counted, multipled by 2 and recorded using a hand lens as Colony Forming Units (CFU) per $100 \mathrm{~m} \ell$.

For quality control, the testing kit was calibrated using a duplicate test on the first and last sample of each day's sampling. The duplicates were rotated for each month's sampling to avoid repetition of control sites. Verification of plate counts was done on all samples by the authors. The verification involved identification of thermotolerant coliforms and enterococci colonies as well as quality control of results for different dilutions. A 95\% confidence level interval was used to define variation in results. Due to elevated levels of colonies on some plates, a wider statistical variability was noted and a $95 \%$ confidence level could not always be achieved.

\section{Water level data collection}

Depth-to-water level was tested using a dipper tape on a monthly basis. The measurements were taken at the same time of day on each day's sampling. Field visits occurred between 7:30 and 12:00 to avoid early morning water collections in the communities. Results were recorded with water quality outcomes in a standard format as metre $(\mathrm{m})$ below ground $(\mathrm{mbg})$.

\section{Results}

Three forms of analysis are presented. These include logistical regression analysis of rainfall to "non- compliance" of microbiological quality as well correlations between the first of flush of rainfall and contamination and the soil type and contamination. Results from the study are presented to demonstrate:

- total rainfall received during the study period

- pathways to contamination following the first flush rains

- correlation between rainfall and contamination levels using regression analysis.

For the purpose of analysis, statistical outliers have been removed from further analysis and are not indicated in this paper. These are defined as 'observations whose values are quite different than others in the data set.' In accordance with the WHO Guidelines for Drinking Water Quality, this study defined statistically 'non-valid' outliers as microbiological results $>1000 \mathrm{cfu}$ (WHO, 2004). 
Median rainfall data (1995-2003) compared to rainfall (2003-4)

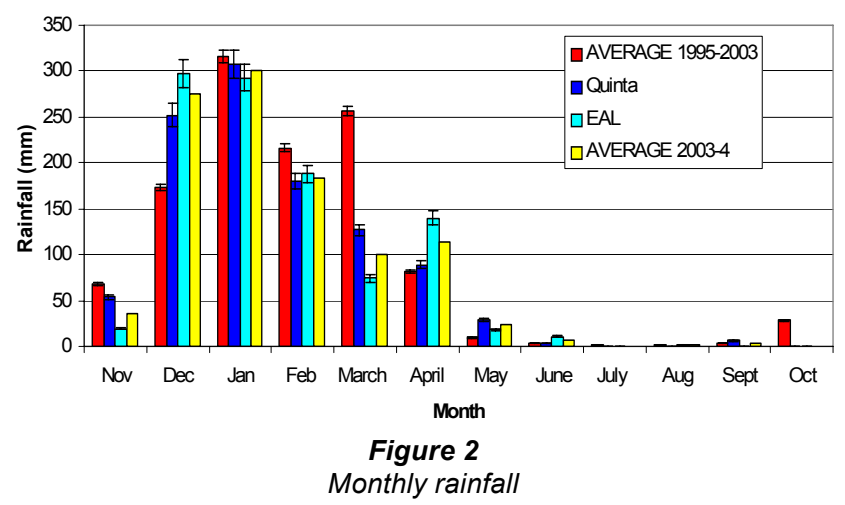

Rainfall

The rainfall distribution during the study was 'typical' with peak periods of rainfall falling between summer period of November 2003 and April 2004. Figure 2 outlines the mean monthly rainfall measure at Raingauge 3 for the period between 1995 and 2003 is compared with data collected from Raingauges 1 and 2 between 2003 and 2004. The average rainfall at each of the three sites in 2003 and 2004 is also shown.

Both Raingauges 1 (Quinta) and 2 (EAL) provide higher average monthly rainfall figures than rainfall recorded at Raingauge 3 over the previous 8 years. The histogram in Fig. 2 illustrates a higher pattern rainfall from Raingauge 2 located on higher ground than Raingauge 1 (located in lower ground). This may be due to the closer proximity of tree cover, "non- readings" during school holidays, location of a Raingauge on lower ground and/or rigour of the data collection undertaken in each gauge.

\section{Rainfall and microbiological contamination}

Prior to November 2003, contamination levels were noted as $<10 \mathrm{cfu} / 100 \mathrm{~m} \ell$ (colony-forming units/100 $\mathrm{m} \ell$ ). Analysis 1 indicates increased levels of microbiological contamination for both TTC and EF (noted as $>10 \mathrm{cfu} / 100 \mathrm{~m} \ell$ ) following the first flush of rainfall. Over the 12-month period, levels of microbiological contamination increased at the beginning of the rains during the month of November where direct pulse response of contamination to rainfall was observed. Figure 3 outlines results obtained for thermotolerant coliforms and enterococci during the start of the rains in November 2003 and December 2004. The results are illustrated as blocks for improved, upgraded and traditional wells. Figure 3 indicates results from samples collected twice during November $\left(14^{\text {th }} / 15^{\text {th }}\right.$ - before the rains and $\left.23^{\text {rd }} / 24^{\text {th }}\right)$ and then once during December $\left(16^{\text {th }} / 17^{\text {th }}\right)$. Rainfall records were collected daily through November and December with the first rains recorded on $15^{\text {th }}$ November microbiological samples were collected.

Statistical outliers, defined in this research as the upper band limit of the WHO Guidelines for Drinking Water Quality of $>1000 \mathrm{cfu} / 100 \mathrm{~m} \ell$ are excluded from all data analyses in this paper (WHO, 2004). An average of 2 outliers was recorded in microbiological results per month. These results are attributed to initial errors due to cross-contamination during laboratory analysis, they have not been discarded as errors but are considered as outliers (described in this context as observations whose values are quite different to others in the data set).

Figure 3 indicates that the levels of recorded contamination increased dramatically following the first flush of heavy rainfall on $15^{\text {th }}$ November. Prior to the rains, low contamination levels

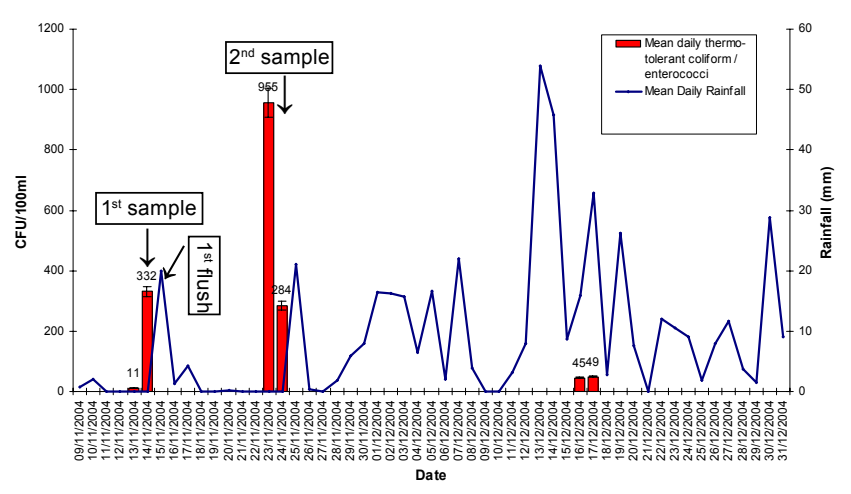

Figure 3

First flush contamination in Lulimile and Nomba

(Nov - Dec 2003)

were recorded in all wells before the peak contamination rates equalled 5 and 10 orders of magnitude for thermotolerant coliforms and enterococci between the first and second sample in November. This is believed to be due to a combination of factors including use of unwashed and highly contaminated buckets for water extraction resulting from limited quantity of water in the wells during this dry period, cross contamination from dirt/ dust entering the wells, possible errors in analysis methods and raised turbidity/total dissolved solids (TDS) masking contaminants and reducing die-off periods. Figure 3 further highlights a rapid "pulse response" of levels of contamination to rainfall with Result 1 on 14/15 November at less than $24 \mathrm{~h}$.

Due to limitations in this paper, annual trends are not outlined in detail. In summary however, contamination reduced slightly during further rains in December and the trend was reflected in the following months, where contamination levels increased following torrential downfalls at the end of January/ February and then began to reduce at the end of the rains in April.

\section{Pathways to contamination}

Analysis 2 involved the determination of the hydrogeological correlation between soil types surrounding the researched wells and contamination. Data were collected using particle size distribution analysis and soil classification tests - see Fig. 4 (CibaGeigy, 1986).

Results indicate a lithology of very high silt and clay content with interspersed impermeable clay layers located at depth to bedrock. The $K$ permeability value for each of the samples suggest a moderate to low permeability range at $10^{-4}-10^{-8} \mathrm{~m} / \mathrm{s}$ (BS5930, 1999) (Taylor et al., 2004). The findings suggest that direct ingress of bacterial contaminants through the study soils to the well receptor is prevented due to the low permeability and depth to water table ( $>8 \mathrm{mbgl}$ ) (Yates, 1989; Robertson et al., 1997; ARGOSS, 2002; Foster et al., 2002). Results therefore suggest that contamination of the wells has occurred through alternative localised pathways. These include identified weaknesses in the engineering headworks such as cracks at the base of hand-pumps, inadequate drainage, seepage through the annuli of concrete caissons or ingress through pumping mains.

\section{Regression models of contamination}

The third analysis involved monthly analysis of the statistical significance of rainfall to microbiological non-compliance at $>10 \mathrm{cfu} / 100 \mathrm{~m} \ell$. Data was "dummy coded" as binomial data in 


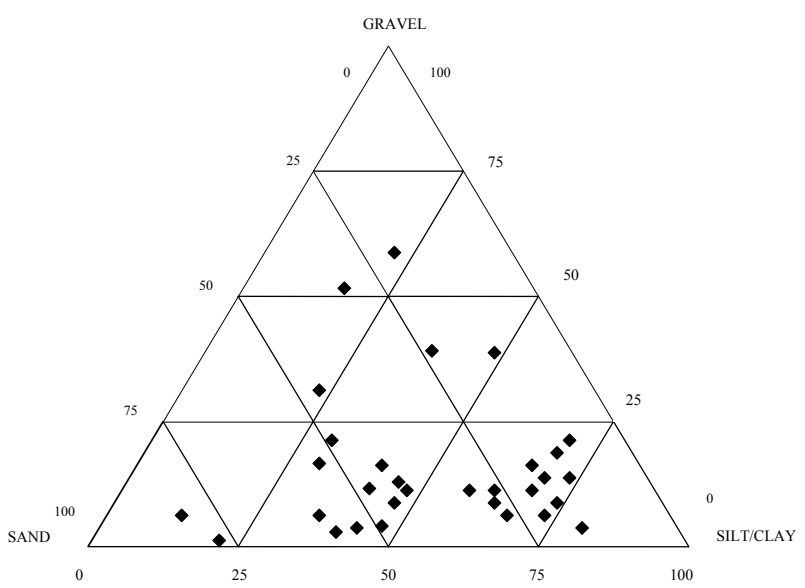

Figure 4

Ternary diagram showing range of particle sizes within the three study areas of Lichinga (depths of 1 to $10 \mathrm{~m}$ )

SPSS Version 10 on a monthly basis. Results were outlined in relation to the influence of both high and low rainfall (where low is defined as $<10 \mathrm{~mm}$ per month) and high rainfall (as defined as $>10 \mathrm{~mm}$ per month) for the three well technology types.

Levels of precision are presented in Table 1 and are estimated based on the output $\mathrm{p}$-value. This provides an estimate of precision that is statistically significant at $95 \%$ confidence or 0.05 . Significant results are noted at a p-value nearer to zero than 0.05 .

\begin{tabular}{|l|l|l|l|l|l|l|}
\hline \multicolumn{7}{|c|}{$\begin{array}{l}\text { TABLE 1 } \\
\text { Rainfall }\end{array}$} \\
\hline & $\begin{array}{l}\text { Traditional } \\
\text { Well }\end{array}$ & $\begin{array}{l}\text { Improved } \\
\text { Well }\end{array}$ & \multicolumn{2}{l|}{$\begin{array}{l}\text { Upgraded } \\
\text { Well }\end{array}$} \\
\hline & TTC & EF & TTC & EF & TTC & EF \\
\hline Rain High & 0.472 & 0.527 & 0.014 & 0.147 & 0.297 & 0.935 \\
\hline Rain Low & 0.963 & 0.852 & & & 0.225 & 0.948 \\
\hline
\end{tabular}

For both traditional and upgraded wells, levels of non-compliance were noted as being of greatest significance during periods of low rainfall. For all well types, levels of microbiological non-compliance were noted as greatest during periods of high rainfall. Rainfall was however only significant in improved wells during peak rains. High $p$ values of $p=0.014$ were noted for TTC indicating a high statistical correlation between TTC contamination and periods of rainfall. Equally, medium levels of compliance were noted for $\mathrm{EF}(\mathrm{p}=0.147)$. Rainfall is slightly less significant in upgraded wells than improved wells during peak rainy periods. However, both traditional and upgraded wells are affected by both high and low rains; whereas improved wells are not affected during periods of low rainfall. In traditional wells, rain alone is not of significance. However, when combined with high risk pathways or high risk sources in the environment, high risk occurs.

All wells are therefore highly susceptible to high rains from both TTC and EF bacteria following first "low" flush of rainfall. Due to poor sanitary completion of many upgraded wells combined with siting of wells in densely populated areas of high vulnerability, high levels of rainfall proved statistically significant.

\section{Discussion}

The analysis of groundwater quality at 25 sites in Lichinga, Northern Mozambique indicates that the microbiological qual- ity of the water increased by an order of 10 after $24 \mathrm{~h}$ of rainfall. Quality recorded in these wells following the rainfall was in excess of the WHO Guidelines for Drinking Water Quality (WHO, 2004). The study further noted a higher level of presumptive enterococci compared to presumptive thermotolerant coliforms. These findings are in line with Bitton et al. (1983) who in sampling of 6 shallow wells for bacterial indicators during periods of intermittent sewerage contamination, noted that both thermotolerant coliforms and enterococci remained stable in the groundwater environment for up to $70 \mathrm{~d}$ (Bitton et al., 1983)

Findings from Lichinga, Mozambique further support similar studies in noting that presumptive enterococci displayed a higher survival function than presumptive thermotolerant coliforms and did not multiple under polluted environments (Bitton et al., 1983; Melian et al., 1999; Macler et al., 2000). The findings indicate that enterococci were consistently more numerous than thermotolerant coliforms both at shallow and deeper depths. This finding supports the opinion that enterococci may be 'a more reliable indicator of faecal pollution than faecal coliforms in raw water' (Massa et al., 2001) The greater survival of enterococci both in the environment and at depth in this study suggests that enterococci may be an ideal additional or alternative indicator organism for bacterial contamination of shallow groundwaters.

\section{Conclusions}

Three conclusions can be drawn from this study. Firstly, the study demonstrates a direct pulse response of microbiological contamination of shallow groundwater to the first flush of rainfall. Levels of microbiological contamination identified in the selected well sites indicate increased levels of contamination of an order of 10 within $24 \mathrm{~h}$ of rainfall suggesting that contamination is occurring through preferential or localised pathways. Secondly, that localised, as opposed to aquifer pathways, may be responsible for rapid contamination following first flush and thirdly that enterococci demonstrated a higher survival rate, both at shallower and deeper depths than thermotolerant coliforms.

\section{Acknowledgement}

The authors wish to acknowledge the support provided by Rebecca van der Meulen, WaterAid Mozambique, Quinta Capriconia and the Lichinga Agricultural Research Centre. The views expressed in this paper are solely those of the authors. Additionally the authors acknowledge the technical and financial support provided by Dr Guy Howard and the UK Water Conservators Company.

\section{References}

ANON (1994) The bacteriological examination of drinking water supplies 1994. Reports on Public Health and Medical Subjects No. 71: Methods for Examination of Waters and Associated Materials. UKDrinking Water Inspector, London.

ARGOSS (2002) Guidelines for Assessing the Risk to Groundwater from On-site Sanitation. British Geological Survey Commissioned Report CR/01/142.

BARNES GE (2000) (2) Soil Mechanics - Principles and Practice. Pelgrave, New York.

BARREL RAE and ROWLAND MGM (1979) The relationship between rainfall and well water pollution in a West African (Gambian) village. J. Hyg. 83143.

BARRET M JOHAL K HOWARD G PEDLEY S and NALUBEGA M 
(2000) Sources of faecal contamination of shallow groundwaters in Kampala. Groundwater: Past Achievements and Future Challenges. DFID, UK.

BARTRAM J (1996) Optimising the monitoring and assessment of rural water supplies. Robens Centre of Environmental Health. University of Surrey, UK.

BITTON G, FARRAH SR, RUSKIN RH, BUTNER J and CHOU YJ (1983) Survival of pathogenic and indicator organisms in groundwater. Groundwater 21 (4) 405.

BS1377-2 (1990) BS 1377-2 Methods of Test for Soils for Civil Engineering Purposes - Part 2 Classification Tests. British Standards Institution (BSI), London, UK.

BS5930 (1999) Code of Practice for Site Investigation. British Standards Institution. (BSI), London, UK.

CIBAGEIGY (1986) Guide to Soil Identification. Ciba Geigy Agrochemicals. UK

FOSTER S, HIRATA R, GOMES D, D'ELIA M and PARIS M (2002) Groundwater Quality Protection - A Guide for Water Utilities, Municipal Authorities and Environment Agencies. Washington DC, USA.

GUNSTON H (1997) Field Hydrology in Tropical Countries - A Practical Introduction. Intermediate Technology Publications, London.

HOWARD G, PEDLEY S, BARRET M, NALUBEGDA M and JOHAL K (2003) Risk factors contributing to microbiological contamination of shallow groundwater in Kampala, Uganda. Water Res. 37 3421 .

LEWIS WJ, FOSTER SD and DRASER BS(1980) The Risk of Groundwater Pollution by On-Site Sanitation in Developing Countries - A
Literature Review. DFID, UK.

LEWIS WJ and CHILTON P J (1984) Performance of sanitary completion measures of wells and boreholes used for rural water supplies in Malawi. Challenges in Afr. Hydrol. Water Resour. 235 235-247.

MACLER BA and MERKLE JC (2000) Current knowledge on groundwater microbial pathogens and their control. Hydrogeol. J. 829.

MASSA S, BROCCHI GF, PERI G, ALTIERI C and MAMMINA C (2001) Evaluation of recovery methods to detect feacal streptococci in polluted waters. Lett. Appl. Microbiol. 32298.

MELIAN R, MYRLIAN N, GOURIEV A, MOURARU C and RADSTAKE F (1999) Groundwater quality and rural drinking water supplies in the republic of Moldova. Hydrogeol. J. 7171.

ROBERTSON JB and EDBERG SC (1997) Natural protection of spring and well drinking water against surface microbial contamination 1. Hydrogeological parameters. CRC Press 143 143-177.

SWARTZ M, MISSTAER BDR, DALY D and FARRELL ER (2003) Assessing subsoil permeability for groundwater vulnerability. Q. J. Eng. Geol. 36 (173-184).

TAYLOR R (2004) The implications of groundwater velocity variations on microbial transport and wellhead protection - Review of field evidence. Published report, University of Surrey.

TINO F (2003) Personal communication. Agricultural Engineer, EAL Lichinga.

UTKILEN H and SUTTON S (1989). Experience and results from a water quality project in Zambia. Waterlines 7 (3) 6.

WAGTECH (2003) Portable Water Testing Laboratory Kit - The Potaflex, Operational Manual.

WHO (2004) (3) Guidelines for Drinking Water Quality. Geneva, Switzerland.

WRIGHT R (1986) The seasonality of bacterial quality of water in a tropical developing country (Sierra Leone). J. Hyg. 9675.

YATES MV and YATES SR (1989) Septic tank setback distances: A way to minimize virus contamination of drinking water. Groundwater 27 (2) 202. 